\title{
Changes in population growth and distribution: A case study of Visakhapatnam city and its Vicinity regions, Andhra Pradesh.
}

\author{
Prof. T.V.KRISHNA \\ Dept. of Geography, Andhra university, Visakhapatnam. \\ DOI: 10.29322/IJSRP.12.01.2022.p12130 \\ http://dx.doi.org/10.29322/IJSRP.12.01.2022.p12130
}

\begin{abstract}
One of the major demographic characteristic features in India is tremendous increase in migrations from rural areas to urban areas, particularly to the metropolitan cities. As a result, the metropolitan cities are experiencing rapid urban population growth not only within the city but also its adjacent region. Due to rapid population growth , the problems created are, changes in the provision of basic amenities such as housing, water supply, sanitation, transportation facilities etc, within the city but also in its vicinity regions. At this Juncture, the prime requirement is to analyze the population growth, distribution, concentration and inter regional changes at micro-level particularly in metropolitan cities and its vicinity regions. Further, these studies became strong base for metropolitan planning of the city in the priority fixation for the provision of basic amenities in the existing and future scenario. Keeping the above aspects under consideration an attempt is made in this paper to analyze the pattern of the population distribution, and concentration and also its changes over the period. For this purpose, the Visakhapatnam city and its vicinity regions is taken for the study.
\end{abstract}

Key words: City, mandals, regions, distribution, growth.

\section{Introduction:}

India is experiencing tremendous increase in migrations from rural areas to urban areas, particularly to the metropolitan cities. As a result, the metropolitan cities are experiencing rapid urban population growth not only within the city but also its adjacent region. Due to rapid population growth, the problems created are, changes in the provision of basic amenities such as housing, water supply, sanitation, transportation facilities etc, within the city but also in its vicinity regions. In this context Visakhapatnam city and its vicinity regions is taken for the study because Visakhapatnam is one of the fastest growing cities in India and also in Asia due to the location of large number of major, medium and minor industries, several head quarters of Government \& NonGovernment organizations, and higher educational institutions and also availability of good network of road, rail, air and sea transportation facilities.

Study area:

Visakhapatnam city and its vicinity regions are situated in the North Eastern coastal part of Visakhapatnam district of Andhra Pradesh. The total geographical area of the study area is 1,72,760 hect which is about $15.5 \%$ of the total geographical area of the Visakhapatnam district. Visakhapatnam city and its vicinity regions grouped into four regions according to their direction around the Visakhapatnam city. The Visakhapatnam city and its vicinity regions includes the geographical areas of Visakhapatnam city (Visakhapatnam urban and rural mandals) and shown as Central region. Padmanabham mandal, Bheemunipatnam mandal, Anandapuram mandals are shown as Northern region. Pendurti mandal Sabbavaram mandals are treated as Western region and Gajuwaka mandal, Anakapalli mandal, Parawada mandal, Pedagantyada mandal and

Fig no.1: Study area showing four Regions and twelve Mandals 


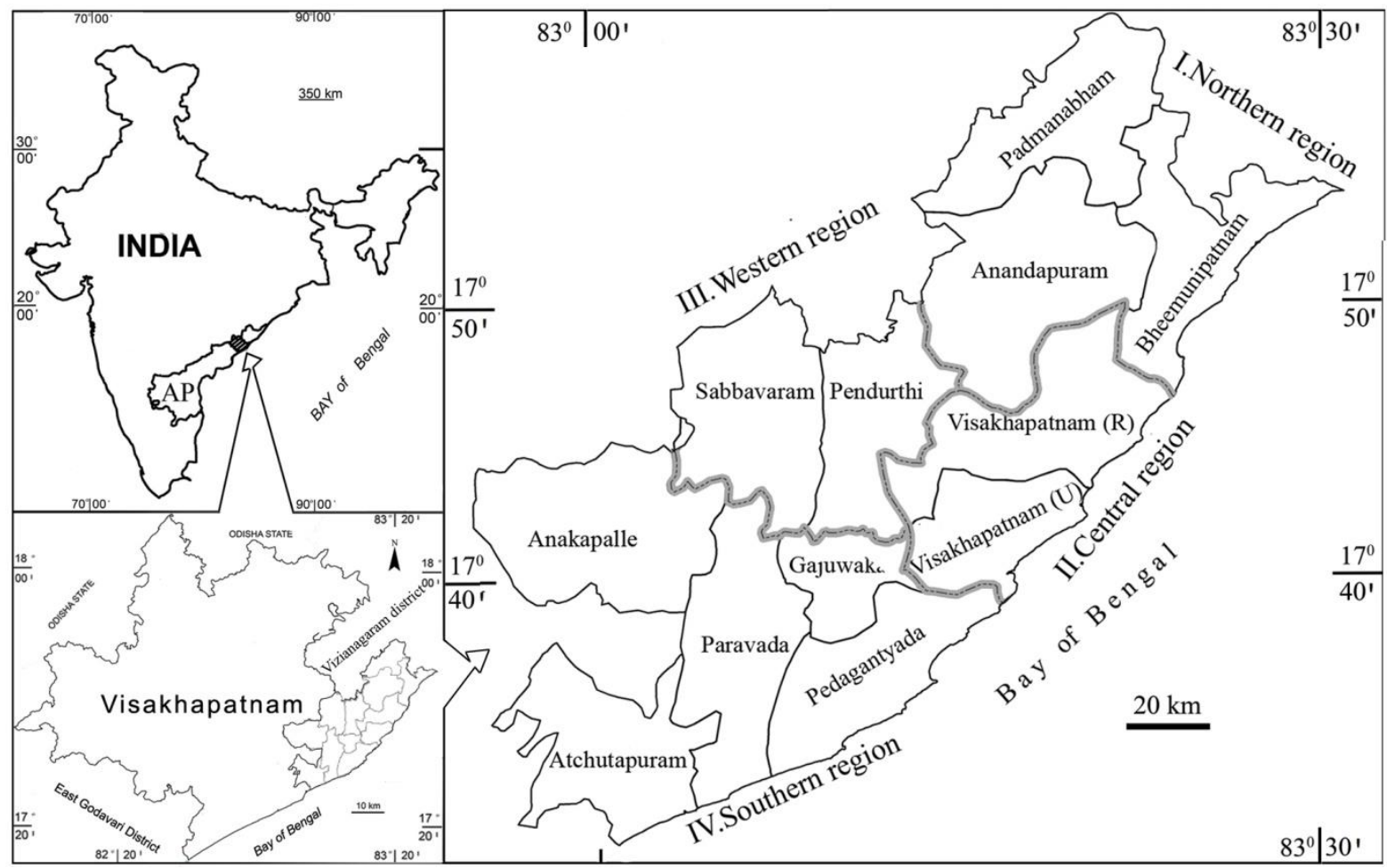

Atchutapuram mandals are treated as Southern region. The total geographical area of the Northern region is 46,356 hectors, Central region (Visakhapatnam U \& R mandals) area 27,048hecorst, Western region area 31,366 hectors, and Southern region 67,990 hectors. All the above said mandals/regions are situated and spread around Visakhapatnam city in the Northern, Western and Southern directions.

\section{Database and Methodology:}

The major data used in this paper are 1961, 1971, 1981, 1991 and 2001 and 2011 census data pertaining to the Visakhapatnam city and its vicinity regions . Apart from this, the village level data which are included in the city also obtained from the census reports in the above mentioned periods. Based on this data the study worked out decadal growth rates, population density and also changes in the population concentration and distribution over the period. The results of the study are as follows.

\section{Results and discussion:}

\section{Pattern of the distribution of population in the study area:}

Table no -1 , showing that, the population of the Visakhapatnam city and its vicinity region has been increased from 5 , 08,390 to $23,58,557$ during 1961 to 2011 period and registered an increase in growth about $364 \%$. Further, the percentage share of the population of the study region is also increased from 29.7 percent to $55 \%$ of the total population of Visakhapatnamdistrict during the study period.

Table no-1: Population growth during 1961 - 2011 periods in the studyregion.

\begin{tabular}{|l|l|l|l|l|l|l|}
\hline $\begin{array}{l}\text { Name of the } \\
\text { Region/mandal }\end{array}$ & 1961 & 1971 & 1981 & 1991 & 2001 & 2011 \\
\hline
\end{tabular}




\begin{tabular}{|l|l|l|l|l|l|l|}
$\begin{array}{l}\text { Population of the } \\
\text { studyRegion } \\
\text { percentage } \\
\text { share) }\end{array}$ & $\begin{array}{l}5,08,390 \\
(29.7 \%)\end{array}$ & $\begin{array}{l}7,34,491 \\
(36 \%)\end{array}$ & $\begin{array}{l}12,02,485 \\
(47 \%)\end{array}$ & $\begin{array}{l}16,39,166 \\
(50 \%)\end{array}$ & $\begin{array}{l}20, \\
11,041 \\
(53.1 \%)\end{array}$ & $\begin{array}{l}23,58,557 \\
(55 \%)\end{array}$ \\
\hline $\begin{array}{l}\text { Populationof } \\
\begin{array}{l}\text { Visakhapatnam } \\
\text { district }\end{array}\end{array}$ & $17,09,777$ & $20,35,831$ & $25,76,474$ & $32,85,092$ & $37,89,823$ & $42,90,589$ \\
\hline
\end{tabular}

Source:Computed form the Census reports of 1961, 1971, 1981, 1991, 2001, 2011of Visakhapatnam District.

\section{Pattern of population growth and distribution according to mandals and regions during 1961-2011 period:}

It may be observed from the table no-2, that, the central region which is a city

( Visakhapatnam urban and rural mandals)contains about $35.8 \%$ of the total population share of the study region in 1961 , which increased to $48 \%$ in 1971 , and $51 \%$ in 1981, and 52.4\% in 2001, and 52.5\% in 2011 census periods and showing continuous positive growth. Whereas population share decreased in Northern region from $18 \%$ in 1961 to $9.8 \%$ in 2011, Western region population share decreased from $13 \%$ in 1961 to $9.1 \%$ in 2011 , and also Southern region population share decreased $33.2 \%$ in 1961 to $28.7 \%$ in 2011 of the total population share of the study region. The percentage share of population concentration in 1961period is relatively higher in Visakhapatnam city(35.8\%) in central region, Anandapuram mandal (6.6\%) in Northern region, Sabbavaram mandal (6.9\%) in Western region,Anakapallimandal(17.9\%) in Southern region. In 1971 period Bheemunipatnam mandal (6.8\%) in Nothern region, Visakhapatnam(48\%) in Central region, Sabbavaram mandal (5.1\%) in Western region, Anakapalli (14.1\%) in Southern region recorded highest population concentration. In 1981period Bheemunipatnam (6.3\%) in Northern region, Visakhapatnam (51\%) in central region, pendurty (4\%) in Western region, Anakapalli (10.8\%) in Southern region recorded highest population concentration. In 1991 period Bheemunipatnam mandal (5.5\%) in Northern region, Visakhapatnam (52\%) in central region, pendurty $(4.2 \%)$ in Western region, Anakapalli mandal (9.9\%) in Southern region, recorded highest population concentration.In 2001 period Bheemunipatnam mandal (5\%) in Northern region, Visakhapatnam $(52.4 \%)$ in central region, pendurty $(5.3 \%)$ in Western region, Gajuwaka (13.9\%) in Southern region recorded highest population concentration. In 2011 period Bheemunipatnam mandal $(4.9 \%)$ in Northern region, Visakhapatnam $(52.5 \%)$ in central region, pendurty $(6.2 \%)$ in Western region, Gajuwaka mandal (10.6\%) in Southern region recorded highest population concentration. While Bheemunipatnam mandal (6.8\%) in Northern region in 1971 census, Pedagantyada mandal (4.5\%) in 1981 census and Visakhapatnam city (53.6\%) in central region, and Gajuwaka mandal (14.2\%) in Southern region in 2001,Visakhapatnam city (52.5\%) in central region,Gajuwaka mandal (10.6\%) in southern region in 2011 census are showing relatively higher population concentrations in respective periods. Further, thepercentage shareof population is rapidly increased in Visakhapatnam city region (from $35.8 \%$ to $52.5 \%$ ) and Gajuwaka mandal (from 3.6\% to 11\%) in Southern region are reported increase in their shares over the period while the rest of the regions are showing decline in their shares over the period.

It is observed from the above discussion that population number is increasing but population share is decreasing in all mandals and all regions of the study region ,but the central region ( Visakhapatnam U\&R mandals) recorded growth in population number and also in population share to the total population of the study region during 1961-2011 period.

Table no - 2: Pattern of population growth and distribution according to mandals/ regions during 1961-2011 periods.

\begin{tabular}{|l|l|l|l|l|l|c|}
\hline $\begin{array}{c}\text { Name of the mandals } \\
\text { and Regions }\end{array}$ & $\begin{array}{c}1961 \\
(\% \text { share })\end{array}$ & $\begin{array}{c}1971 \\
(\% \text { share })\end{array}$ & $\begin{array}{c}1981 \\
(\% \text { share })\end{array}$ & $\begin{array}{c}1991 \\
(\% \text { share })\end{array}$ & $\begin{array}{c}2001 \\
(\% \text { share })\end{array}$ & $\begin{array}{c}2011 \\
(\% \text { share })\end{array}$ \\
\hline I). Northern Region
\end{tabular}




\begin{tabular}{|c|c|c|c|c|c|c|}
\hline 1.Padmanabham & $\begin{array}{l}24,882 \\
(4.9 \%)\end{array}$ & $\begin{array}{l}28,110 \\
(3.8 \%)\end{array}$ & $\begin{array}{l}42,345 \\
(3.5 \%)\end{array}$ & $\begin{array}{l}47,475 \\
(2.9 \%)\end{array}$ & $\begin{array}{l}49,622 \\
(2.5 \%)\end{array}$ & $\begin{array}{l}52,079 \\
(2.2 \%)\end{array}$ \\
\hline 2. Bheemunipatnam & $\begin{array}{l}33,152 \\
(6.5 \%)\end{array}$ & $\begin{array}{l}50,120 \\
(6.8 \%)\end{array}$ & $\begin{array}{l}76,422 \\
(6.3 \%)\end{array}$ & $\begin{array}{l}90,203 \\
(5.5 \%)\end{array}$ & $\begin{array}{l}99,620 \\
(5.0 \%)\end{array}$ & $\begin{array}{l}1,16,349 \\
(4.9 \%)\end{array}$ \\
\hline 3. Anandapuram & $\begin{array}{l}33,654 \\
(6.6 \%)\end{array}$ & $\begin{array}{l}28,756 \\
(3.9 \%)\end{array}$ & $\begin{array}{l}40,226 \\
(3.3 \%)\end{array}$ & $\begin{array}{l}48,107 \\
(2.9 \%)\end{array}$ & $\begin{array}{l}55,525 \\
(2.8 \%)\end{array}$ & $\begin{array}{l}60,789 \\
(2.6 \%)\end{array}$ \\
\hline \multicolumn{7}{|l|}{ II. Central Region } \\
\hline $\begin{array}{l}\text { 1. Visakhapatnam City } \\
\text { ( VSP U\&R mandals) }\end{array}$ & $\begin{array}{l}1,82,004 \\
(35.8 \%)\end{array}$ & $\begin{array}{l}3,52,504 \\
(48 \%)\end{array}$ & $\begin{array}{l}6,13,823 \\
(51 \%)\end{array}$ & $\begin{array}{l}8,57,285 \\
(52 \%)\end{array}$ & $\begin{array}{l}10,53,527 \\
(52.4 \%)\end{array}$ & $\begin{array}{l}12,37,963 \\
(52.5 \%)\end{array}$ \\
\hline \multicolumn{7}{|l|}{ III. Western Region } \\
\hline 1. Pendurthy & $\begin{array}{l}31,323 \\
(6.2 \%)\end{array}$ & $\begin{array}{l}35,362 \\
(4.8 \%)\end{array}$ & $\begin{array}{l}48,283 \\
(4.0 \%)\end{array}$ & $\begin{array}{l}69,122 \\
(4.2 \%)\end{array}$ & $\begin{array}{l}1,06,513 \\
(5.3 \%)\end{array}$ & $\begin{array}{l}1,46,650 \\
(6.2 \%)\end{array}$ \\
\hline 2. Sabbavaaram & $\begin{array}{l}34,999 \\
(6.9 \%)\end{array}$ & $\begin{array}{l}37,669 \\
(5.1 \%)\end{array}$ & $\begin{array}{l}44,760 \\
(3.7 \%)\end{array}$ & $\begin{array}{l}51,861 \\
(3.2 \%)\end{array}$ & $\begin{array}{l}59,272 \\
(2.9 \%)\end{array}$ & $\begin{array}{l}67,334 \\
(2.9 \%)\end{array}$ \\
\hline \multicolumn{7}{|l|}{ IV. Southern Region } \\
\hline 1. Gajuwaka & $\begin{array}{l}18,166 \\
(3.6 \%)\end{array}$ & $\begin{array}{l}24,904 \\
(3.4 \%)\end{array}$ & $\begin{array}{l}64,182 \\
(5.3 \%)\end{array}$ & $\begin{array}{l}1,43,073 \\
(8.7 \%)\end{array}$ & $\begin{array}{l}2,79,672 \\
(13.9 \%)\end{array}$ & $\begin{array}{l}2,50,423 \\
(10.6 \%)\end{array}$ \\
\hline 2. Anakapalli & $\begin{array}{l}91,183 \\
(17.9 \%)\end{array}$ & $\begin{array}{l}1,03,446 \\
(14.1 \%)\end{array}$ & $\begin{array}{l}1,30,001 \\
(10.8 \%)\end{array}$ & $\begin{array}{l}1,62,652 \\
(9.9 \%)\end{array}$ & $\begin{array}{l}1,76,822 \\
(8.8 \%)\end{array}$ & $\begin{array}{l}1,86,937 \\
(7.9 \%)\end{array}$ \\
\hline 3. Paravada & $\begin{array}{l}21,802 \\
(4.3 \%)\end{array}$ & $\begin{array}{l}29,742 \\
(4.0 \%)\end{array}$ & $\begin{array}{l}43,249 \\
(3.60 \%)\end{array}$ & $\begin{array}{l}48,824 \\
(3.0 \%)\end{array}$ & $\begin{array}{l}58,828 \\
(2.9 \%)\end{array}$ & $\begin{array}{l}78,165 \\
(3.3 \%)\end{array}$ \\
\hline 4. Pedagantyada & NA & NA & $\begin{array}{l}53,002 \\
(4.4 \%)\end{array}$ & $\begin{array}{l}65,552 \\
(4.0 \%)\end{array}$ & $\begin{array}{l}12,741 \\
(0.6 \%)\end{array}$ & $\begin{array}{l}95,291 \\
(4.0 \%)\end{array}$ \\
\hline 5. Atchutapuram & $\begin{array}{l}37,265 \\
(7.3 \%)\end{array}$ & $\begin{array}{l}43,888 \\
(6.0 \%)\end{array}$ & $\begin{array}{l}46,192 \\
(3.8 \%)\end{array}$ & $\begin{array}{l}55,012 \\
(3.4 \%)\end{array}$ & $\begin{array}{l}58,899 \\
(2.9 \%)\end{array}$ & $\begin{array}{l}66,577 \\
(2.8 \%)\end{array}$ \\
\hline $\begin{array}{l}\text { Total population of the } \\
\text { study region }\end{array}$ & $5,08,390$ & $7,34,491$ & $12,02,485$ & $16,39,166$ & $20,11,041$ & $23,58,557$ \\
\hline
\end{tabular}

(Percentage of population share to the total population of the study area)

Source: Computed from the census reports of 1961, 1971, 1981, 1991, 2001 and 2011 of Visakhapatnam Dt.

Pattern of decadal changes in population growth according to mandals and regions during 1961-2011 period :

Fig no-2 showing decadal population growth during 1961-2011 period in the study region. Regarding regions, highest decadal growth rate recorded in Central region with about 580\% during 1961-2011 (50years) period with 50\% average decadal growth rate. Southern region recorded second highest growth rate with about 302.2\%growth rate during 1961-2011 period with $33 \%$ decadal average growth rate.Western region occupied third highest growth rate with about $222.2 \%$ growth rate during 1961 - 
2011 period with $27 \%$ average decadal growth rate. Lowest growth rate recorded in Northern region with about $150 \%$ growth rate during 1961-2011 period with 21\% average decadal growth rate. Regarding mandals, maximum extent of population growth is found in Bheemunipatnam (251\%)of Northern region, Sabbavaram (92.4\%) in Western region, Gajuwaka (1278\%) in Southern region, Visakhapatnam city (580\%) in central region, are reported maximum population growth during 1961-2011 among regions. Further, the regions such as Bheemunipatnam, Visakhapatnam city, Gajuwaka, Paravada, Anakaalli, Atchutapuram regions are reported more than $100 \%$ population growth during this period. The percentage of growth of the regions is ranges between $7.60 \%$ to $93.7 \%$ during $1961-1971,5.2 \%$ to $74.10 \%$ during $1971-1981,12.9 \%$ to $123 \%$ during $1981-1991$ and $4.5 \%$ to $95.5 \%$ during 1991-2001, and 4.9\% to $648 \%$ in $2001-2011$ period. Further, the maximum population growth is found in Visakhapatnam city region during 1961-1971 (93.7\%) \& 1971-1981 (74.1) and Gajuwaka region during 1981-1991 (123\%) and 1991-2001 (95.5\%) among regions. However, the Gajuwaka region registered decline(-10.5\%) in population growth during 2001-2011 period. Further, the Visakhapatnam city in 1961-1971, Visakhapatnam city and Gajuwaka in 1971-81,Visakhapatnam city, Pedagantyada and Gajuwaka regions in 1981-1991, Visakhapatnam city, Pendurty, Gajuwaka in 1991-2001, Bheemunipatnam, Visakhapatnam city, Pendurty, Paravada and Pedagantyada during 2001-2011 period, are reported relatively higher extent of growth when compared to the figures of study area as a whole. Further, about 4 regions (36.36\%) such as Bheemunipatnam in Northern region, Visakhapatnam city in central region, Gajuwaka and Paravada in Southern region in 1961-71, 7 regions (63.63\%) such as Padmanabham, Bhemunipatnam and Anandapuram in Nothern region, Visakhapatnam city in central region, Pendurthi in west region, Gajuwaka and Paravada in Southern region in 1971-81, 3 regions (27.27\%) such as Visakhapatnam city, Pendurthy, Gajuwaka in 1981-91 and 4 regions (36.36\%) in 1991-2001, such as Visakhapatnam city, Pendurthy, Gajuwaka and Paravada regions, 5 regions $(71 \%)$ such as Bheemunipatnam, Visakhapatnam city, Pendurthy, Paravada, Pedagantyada in 20012011 period, are reported relatively higher extent of population growth when compared to the figures of the district in respective periods. Another important aspect is that maximum population growth rate (63.7\%) is reported during 1971-81, and lowest population growth is recorded in 2001-2011 period (17.3\%) during 1961-2011 periods.

Fig no.2: Pattern of decadal changes in population growth according to regions during 1961-2011 periods: 

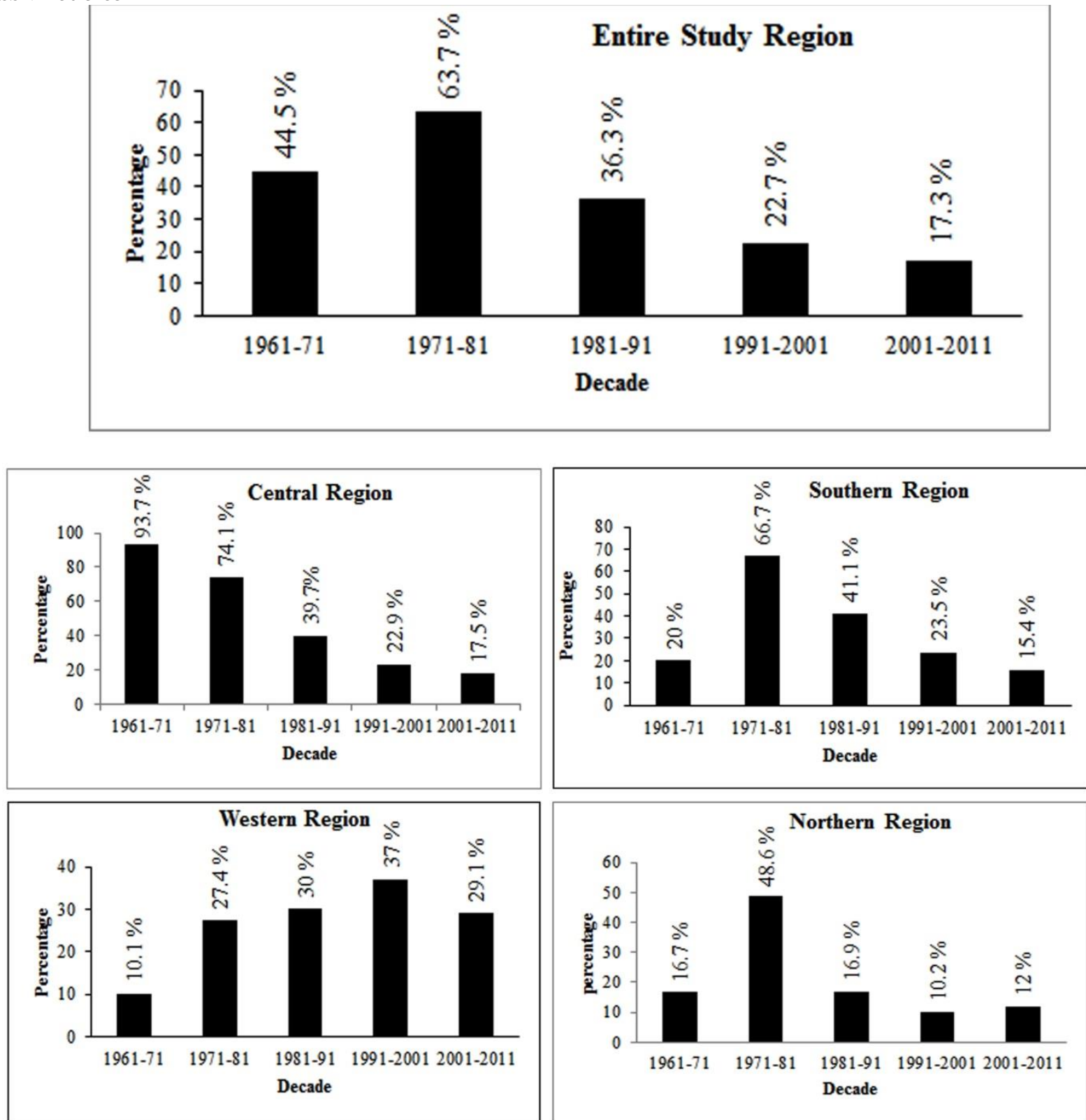

Table no.3: Population density changes pattern of changes in population density in the study area during1981-2011 period

\begin{tabular}{|c|c|c|c|c|c|c|c|}
\hline $\begin{array}{l}\text { Name of the } \\
\text { mandal/ } \\
\text { Region }\end{array}$ & 1981 & 1991 & 2001 & 2011 & $\begin{array}{l}\text { Changes } \\
\text { during } \\
1981 \\
1991\end{array}$ & Changes & $\begin{array}{l}\text { Changes } \\
\text { during } \\
2001- \\
2011\end{array}$ \\
\hline \multicolumn{8}{|c|}{ I). Northern region } \\
\hline 1.Padmanabham & 310 & 346 & 360 & 377 & $11.61 \%$ & $4.05 \%$ & $4.7 \%$ \\
\hline
\end{tabular}




\begin{tabular}{|c|c|c|c|c|c|c|c|}
\hline $\begin{array}{l}2 . \\
\text { Bheemunipatnam }\end{array}$ & 614 & 722 & 791 & 962 & $17.59 \%$ & $9.56 \%$ & $21.6 \%$ \\
\hline 3. Anandapuram & 196 & 235 & 269 & 297 & $19.9 \%$ & $14.47 \%$ & $10.4 \%$ \\
\hline \multicolumn{8}{|l|}{ II. Central Region } \\
\hline 1.Visakhapatnam & & & & & & & \\
\hline $\begin{array}{l}\text { City ( VSP } \\
\text { U\&R mandals) }\end{array}$ & 2306 & 2827 & 2869 & 4783 & $22.59 \%$ & $1.49 \%$ & $66.7 \%$ \\
\hline \multicolumn{8}{|c|}{ III. Western Region } \\
\hline 1. Pendurthy & 431 & 617 & 949 & 1222 & $43.16 \%$ & $53.81 \%$ & $28.8 \%$ \\
\hline 2. Sabbavaaram & 275 & 320 & 366 & 349 & $16.36 \%$ & $184.69 \%$ & $-4.6 \%$ \\
\hline \multicolumn{8}{|c|}{ IV. Southern Region } \\
\hline 1. Gajuwaka & 392 & 1703 & 2587 & 2782 & $334.44 \%$ & $51.91 \%$ & $7.5 \%$ \\
\hline 2. Anakapalli & 508 & 884 & 1006 & 1016 & $74.02 \%$ & $13.8 \%$ & $1.0 \%$ \\
\hline 3. Paravada & 314 & 354 & 427 & 518 & $12.73 \%$ & $172.88 \%$ & $21.3 \%$ \\
\hline 4. Pedagantyada & 530 & 655 & 129 & 908 & $23.58 \%$ & $-80.31 \%$ & $603.9 \%$ \\
\hline 5. Atchutapuram & 319 & 379 & 401 & 441 & $18.81 \%$ & $5.8 \%$ & $10.0 \%$ \\
\hline $\begin{array}{ll}\text { Total } & \text { study } \\
\text { region } & \end{array}$ & 536 & 822 & 923 & 1241 & $46 \%$ & $24.2 \%$ & $34.5 \%$ \\
\hline $\begin{array}{l}\text { Visakhapatnam } \\
\text { District }\end{array}$ & 231 & 294 & 340 & 384 & $27.27 \%$ & $15.65 \%$ & $13.0 \%$ \\
\hline
\end{tabular}

Source: Data computed from the census reports of 1961, 1971, 1981, 1991, 2001,2011 of Visakhapatnam District.

Table no 3 shows that, the entire study region reported relatively high extent of population density i.e., 536 persons/ sq. Km in 1981, 822 in 1991 and 923 in 2001 and 384 in 2011 period when compared to the figures of the Visakhapatnam district and state in all most all periods. In respect of change, the maximum percentage of increase in population density is found in Gajuwaka (334.4\%) during 1981-91, Sabbavaram (184.69\%) during 1991-2001, Pedagantyada (603.9\%) during 2001-2011 period among regions.Further, about 2 regions (18.18\%) such as Gajuwaka and Anakapalli during 1981-1991, 4 regions (36.36\%) such as Pendurthy, Sabbavaram, Gajuwaka and Paravada during 1991-2001 5 regions (45.45\%) such as Pendurty, Sabbavaram, Gajuwaka, Anakapalli and Pravada during 1981-2001 are reported more than 50 percent increase in population density in respective periods. Moreover about 3 percentage (27.27\%) in 1981-91, and 5 regions (45.45\%) during 1991-2001 are reported relatively higher extent of increase in population density when compared to the figures of the study area as a whole. Similarly, about 3 regions (27.27\%) in 1981-91, and 5 population density when compared to the figures of the district, while about 3 regions (36.36\%) during 1981-1991, 5 regions (45.45\%) during 1991-2001 are reported relatively higher extent of increase in population density contrast to the figures of the state

\section{CONCULSION:}

It is evident from the above analysis that, almost all the regions of Visakhapatnam city and its vicinity regions are showing higher extent of growth in population and also increase in the population density over the period when compared to the figures of the district and also state. Nearly half of the population of the district is concentrated in Visakhapatnam city region as a whole. Further, it may be concluded that the regions such as Bheemunipatnam mandal, Anandapuram mandal in Northern region, Visakhapatnam city regions, Pendurthy mandal in Western region and Gajuwaka mandal and Paravada mandals in Southern region are not only showing higher concentration of population but also reported higher extent of population growth and density over the period. Moreover, the study predicts that this similar trend could be extended to beyond these regions in short and long 
term perspectives. Hence, the study suggest that top priority must be given to the above mentioned vicinity regions to provide basic amenities such as Water, housing and related activities in urban and metropolitan planning.

\section{References:}

1. Aerni, P. (2016). Coping with Migration-Induced Urban Growth: Addressing the Blind Spot of UN-Habitat. Sustainability, 8, 800 .

2. Berry,J.L.B,(1963), Urban population densities - structure and change, review, 53:389-405

3. Bhagat, R.B. and SoumyaMohanty. (2009), "Emerging pattern of urbanization and the contribution of migration in urban growth in India," Asian Population Studies 5(1): 5- 20.

4. Brauw, A.; Mueller, V.; Lee, H.L. (2014), the Role of Rural-Urban Migration in the Structural Transformation of SubSaharan Africa. World Dev. 63, 33-42.

5. Ecker Charles, M. (2007), "Urbanization and rural-urban migration," in AmitavaDutt and Jaime Ros (eds.). International Handbook of Development Economics. Cheltenham: Edward Elgar, pp. 516- 532

6. Fox, S.; Goodfellow, T. (2016), Cities and Development, 2nd ed.; Routledge: New York, NY, USA,

7. Hanspal, Rajana (1977), urban structure of Bangalore city: A spatial analysis (unpublished Ph.D. thesis). Institute for Social and Economic change, Bangalore.

8. Kessides, C. (2007), the Urban Transition in Sub-Saharan Africa: Challenges and Opportunities. Environ. Plan. C 25, 466-485.

9. Kundu, Amitabh. (2011), Trends and processes of Urbanisation in India, Human Settle Group and UNPD, Urbanization and Emerging Population Issues 6.

10. Neuwirth, R. (2006), Shadow Cities: A Billion Squatters, A New Urban World; Routledge: New York, NY, USA,

11. National Research Council. (2003), Cities Transformed - Demographic Change and its Implication in the Developing World. Washington DC: The National Academy Science

12. Prakasa Rao, V.L.S and V.K. Tiwari (1978),Urbanisation in India - spatial dimension, Institute of Social and Economic change, Bangalore.

13. Yigitcanlar, T.; Teriman, S. (2015), Rethinking Sustainable Urban Development: Towards an Integrated Planning and Development Process. Int. J. Environ. Sci. Technol. 12, 341-352.

14. Zeng, C.; Deng, X.; Dong, J.; Hu, P. (2016), Urbanization and Sustainability: Comparison of the Processes in "BIC" Countries. Sustainability, $8,400$. 